\title{
Genetic diversity of avian infectious bronchitis coronavirus strains isolated in China between 1995 and 2004
}

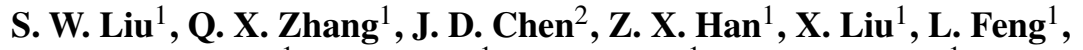

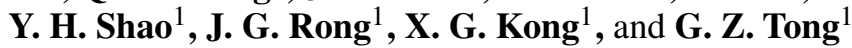 \\ ${ }^{1}$ National Key Laboratory of Veterinary Biotechnology, Harbin Veterinary \\ Research Institute, Chinese Academy of Agricultural Science, Harbin, P.R. China \\ ${ }^{2}$ College of Veterinary Medicine, South China Agricultural University, \\ Guangzhou, P.R. China
}

Received August 24, 2005; accepted November 17, 2005

Published online January 9, 2006 (C) Springer-Verlag 2006

\begin{abstract}
Summary. Twenty-six avian infectious bronchitis (IB) viruses (IBV) were isolated from outbreaks in chickens in China between 1995 and 2004. They were characterized by comparison with twenty-six Chinese reference strains and five other IBV strains. Chinese IBVs, which were mainly nephropathogenic, were placed into seven genotypes. Fourteen Chinese IBV isolates were placed in genotype I, having small evolutionary distances from each other. Genotype II included 6 strains that were isolated in the 1990s in China. Genotype III consisted of eight Chinese isolates that showed close relationship with Korean IBV isolates. Another eight IBV isolates clustered in genotype IV and showed larger evolutionary distances. The Massachusetts serotype was present in China in 1990s and was in a separate genotype. Two isolates, HN99 and CK/CH/LHN/00I, which might be a reisolation of vaccine strains, clustered into genotype VI. Four Chinese IBV isolates formed another genotype and showed larger evolutionary distances from other Chinese IBV genotypes (genotype VII). IBVs in same genotypes showed more than $90 \%$ amino acid sequence similarities, whereas most of the viruses in different genotypes showed less than $90 \%$. The results showed that IBVs in China came from genetic changes both in IBV populations that existed before the advent of vaccination and in the viruses that were introduced through live vaccines. IBVs showing various genetic differences are cocirculating in China.
\end{abstract}

\section{Introduction}

Infectious bronchitis virus (IBV) is a highly infectious and contagious pathogen of chickens worldwide [11]. The primary tissue of IBV infection is the respiratory tract, though some isolates replicate in the kidney and oviduct, resulting 
in nephritis and reduced egg production. Generally, infectious bronchitis (IB) has been controlled with serotype-specific vaccines, but outbreaks of IB still occur, because vaccines offer little cross-protection between serologically distinct viruses [19]. A high mutation frequency and RNA recombination leads to the emergence of new viruses capable of causing disease in vaccinated chickens [31, 41, 35]. Although many countries share some common antigenic types, IBV strains within a geographic region are unique and distinct $[1,4,15-17,21,47]$. The identification of the circulating IBV field strains is extremely important for the selection of vaccine strains for the corresponding geographical region.

IBV is the type species of the genus Coronavirus in the family Coronaviridae, order Nidovirales [11]. It is a pleomorphic enveloped virus and has a singlestranded RNA genome, approximately $27 \mathrm{~kb}$ in length, of positive polarity that specifies the production of three major structural proteins: the phosphorylated nucleocapsid $(\mathrm{N})$ protein, the membrane $(\mathrm{M})$ glycoprotein, and the spike (S) glycoprotein. The S glycoprotein of IBV, located on the outside of all virions, is responsible for fusion (virus envelope to cell membrane and cell membrane to cell membrane) and is translated as a precursor protein $\left(\mathrm{S}_{0}\right)$, then cleaved into a carboxy-terminal S2 subunit (approximately 625 amino acid residues), which anchors $\mathrm{S}$ in the virus envelope, and an amino-terminal S1 subunit (approximately 520 residues), believed to largely form the distal bulbous part of $S[3,7]$.

The S1 subunit of spike glycoprotein of IBV is responsible for inducing neutralizing and serotype-specific antibodies in chickens, and mutations in the antigenically important spike glycoprotein S1 subunit leads to the emergence and proliferation of variant serotypes [34] associated with disease outbreaks. Serotypic evolution in IBV is associated primarily with the sequences of the $\mathrm{S} 1$ glycoprotein, and the genetic diversity of IBV is mainly monitored by analysis of the S1 gene $[2,9,10,23,27,32,42]$.

IBV strains have been isolated and identified since 1982 in China. The outbreaks of IB have been ongoing, and IB continues to be an economically important disease to the poultry industry, although vaccines based on Massachusetts (Mass) strains such as H120 and H52 have been used for many years. However, the epidemiological analysis of IBV isolates in China has not been thorough except for with a few strains $[31,28,46]$. The relationships between Chinese IBV isolates and foreign IBV isolates, especially Korean, Taiwanese and Japanese IBV isolates, are not known. The focus of this study was to determine the molecular typing of the spike glycoprotein S1 subunit of IBV isolated between the years 1995 and 2004 in China. This will determine the IBV type(s) which are necessary for understanding the epidemiology and evolution of IBVs, as well as isolation of the virus, which is important for improved vaccination.

\section{Materials and methods}

Virus isolation and propagation

Twenty-six field IBVs were isolated from kidney, preventriculus, or oviduct of IB-suspected broilers or layers using specified pathogen-free (SPF) embryonated eggs between 1995 
Table 1. IBV strains isolated from flocks in different provinces of China

\begin{tabular}{|c|c|c|c|c|c|}
\hline IBV isolates & Province $^{\mathrm{a}}$ & $\begin{array}{l}\text { Years of } \\
\text { isolation }\end{array}$ & $\begin{array}{l}\text { Organs }{ }^{b} \text { used } \\
\text { for virus } \\
\text { isolation }\end{array}$ & $\begin{array}{l}\text { Production } \\
\text { type }\end{array}$ & $\begin{array}{l}\text { Chicken } \\
\text { embryo } \\
\text { passage }^{c}\end{array}$ \\
\hline CK/CH/LTJ/95I & Tianjin & 1995 & kidney & layer hen & 3 \\
\hline CK/CH/LHLJ/95I & Heilongjiang & 1995 & kidney & layer hen & 5 \\
\hline CK/CH/LSC/95I & Sichuan & 1995 & kidney & layer hen & 5 \\
\hline CK/CH/LHB/96I & Hebei & 1996 & kidney & broiler & 3 \\
\hline CK/CH/LGD/96I & Guangdong & 1996 & kidney & layer hen & 6 \\
\hline CK/CH/LDL/97I & Liaoning & 1997 & preventriculus & layer hen & 5 \\
\hline CK/CH/LLN/98I & Liaoning & 1998 & kidney & broiler & 6 \\
\hline CK/CH/LDL/98I & Liaoning & 1998 & preventriculus & layer hen & 3 \\
\hline CK/CH/LHLJ/99I & Heilongjiang & 1999 & preventriculus & layer hen & 3 \\
\hline CK/CH/LSC/99I & Sichuan & 1999 & preventriculus & layer hen & 3 \\
\hline CK/CH/LAH/99I & Anhui & 1999 & kidney & layer hen & 7 \\
\hline CK/CH/LHN/0OI & Henan & 2000 & preventriculus & broiler & 3 \\
\hline CK/CH/LDL/01I & Liaoning & 2001 & oviduct & layer hen & 7 \\
\hline CK/CH/LXJ/02I & Xinjiang & 2002 & kidney & layer hen & 4 \\
\hline CK/CH/LHLJ/02I & Heilongjiang & 2002 & kidney & layer hen & 2 \\
\hline CK/CH/LSHH/03I & Shanghai & 2003 & kidney & broiler & 3 \\
\hline CK/CH/LSHH/03II & Shanghai & 2003 & kidney & broiler & 3 \\
\hline CK/CH/LGD/03I & Guangdong & 2003 & kidney & layer hen & 5 \\
\hline $\mathrm{CK} / \mathrm{CH} / \mathrm{LAH} / 03 \mathrm{I}$ & Anhui & 2003 & kidney & layer hen & 7 \\
\hline CK/CH/LSD/03I & Shandong & 2003 & kidney & layer hen & 4 \\
\hline CK/CH/LJL/04I & Jilin & 2004 & preventriculus & layer hen & 5 \\
\hline CK/CH/LHLJ/04V & Heilongjiang & 2004 & kidney & broiler & 3 \\
\hline CK/CH/LDL/04II & Liaoning & 2004 & kidney & broiler & 4 \\
\hline CK/CH/LGD/04II & Guangdong & 2004 & kidney & layer hen & 5 \\
\hline CK/CH/LGD/04III & Guangdong & 2004 & kidney & layer hen & 5 \\
\hline CK/CH/LHLJ/04XI & Heilongjiang & 2004 & kidney & layer hen & 3 \\
\hline
\end{tabular}

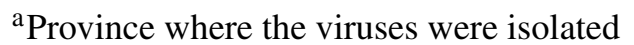

${ }^{\mathrm{b}}$ Kidney $=$ Swollen kidney, Preventriculus $=$ Swollen preventriculus, Oviduct $=$ Atrophic oviduct

${ }^{\mathrm{c}}$ Different passages were performed until the dwarfing and death of embryos were observed between 2 and 7 days after inoculation
}

and 2004 in different parts of China (Table 1 and Fig. 1). For virus isolation, samples of kidney, preventriculus, or oviduct (Table 1) were pooled and $10 \% \mathrm{w} / \mathrm{v}$ tissue suspensions were made in $0.1 \%$ phosphate-buffered saline containing $100 \mathrm{u}$ penicillin and $100 \mu \mathrm{g}$ streptomycin $/ \mathrm{ml}$. After $12 \mathrm{~h}$ at $4{ }^{\circ} \mathrm{C}, 200 \mu \mathrm{l}$ supernatant from the suspensions was inoculated into the allantonic cavity of 9- to 11-day-old embryos. Three to 5 eggs were used for each sample. The inoculated eggs were incubated at $37^{\circ} \mathrm{C}$ and candled daily. Two to 7 blind passages were performed until the characteristic embryo changes such as the dwarfing, stunting, or curling of embryos were observed between 2 and 7 days after inoculation [12]. All allantoic fluids were harvested and tested for the presence of IBV using electron microscopy. 


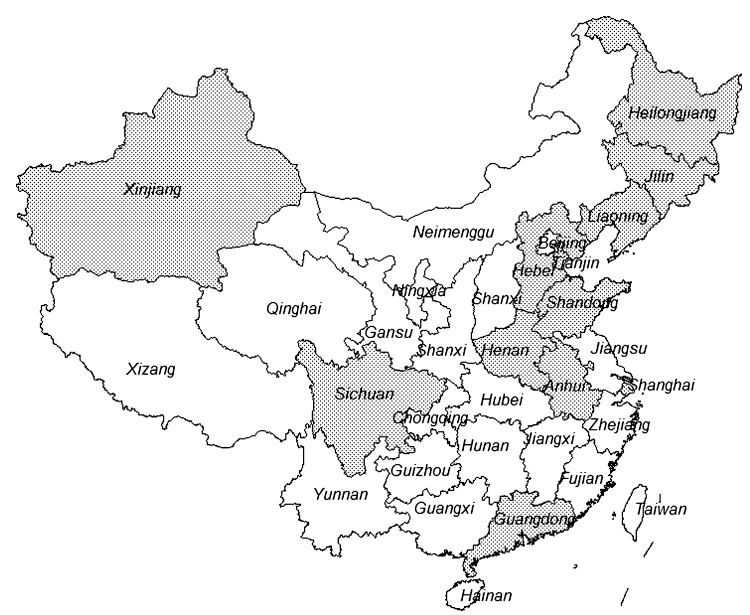

Fig. 1. Location of provinces (shaded) where the IBV strains were isolated in China

\section{Electron microscopy}

Samples of allantoic fluids were submitted for electron microscopy. Briefly, after low-speed centrifugation at $1500 \mathrm{~g}$ for $30 \mathrm{~min}$ (Allegra ${ }^{\mathrm{TM}} 21 \mathrm{R}$ centrifuge; Beckman), the supernatant of the $1.5 \mathrm{ml}$ allantoic fluids were centrifuged at $12000 \mathrm{~g}$ for $30 \mathrm{~min}$. The resulting pellet was resuspended in a minimal volume of deionized water and examined by negative contrast electron microscope (JEM-1200, EX).

\section{Viral RNA extraction, RT-PCR amplification, and sequencing}

Genomic RNA was extracted from virus-inoculated allantoic fluid with TRIzol reagent (Invitrogen) following the manufacturer's instructions. The first-strand cDNA was synthesized according the procedures of a previous report [31] using S1Oligo3' [25] and genomic antisense IBV-212 oligonucleotide, 5'-ATACAAAATCTGCCATAA-3'. IBV-212 was designed based on a comparison and alignment of the GenBank sequences of several known Chinese IBV strains and situated in the downstream of S1Oligo3' which had $5 \mathrm{nt}$ overlapped between them. The PCR profiles involved an initial denaturation for $5 \mathrm{~min}$ at $95^{\circ} \mathrm{C}$ followed by 30 cycles of denaturation at $94^{\circ} \mathrm{C}$ for $1 \mathrm{~min}$, annealing at $50^{\circ} \mathrm{C}$ for $1 \mathrm{~min}$, and polymerization at $72^{\circ} \mathrm{C}$ for $2 \mathrm{~min}$. The final polymerization step was performed at $72^{\circ} \mathrm{C}$ for $10 \mathrm{~min}$. Owing to genetic variations among IBV isolates, it is difficult to design PCR primers that can be used to detect all IBV isolates. Therefore, three genome-sense oligonucleotides, S1Oligo5' [25], S1Uni2 [1], or IBV-87, 5'-TATTGATTAGAGATGTTGGG-3', which was selected from conserved areas by aligning several known Chinese IBV sequences from GenBank, were used with S1Oligo3' [25] or IBV-212 as antisense primer (Table 2). The PCR products were analyzed on a $1.0 \%$ agarose gel and were sequenced directly. In addition, PCR products were also sequenced after cloning into the pMD18-T vector (TaKaRa). Each region was sequenced at least three times from two PCR products from different RT reactions.

\section{Sequence analysis of the S1 protein genes}

The nucleotide and amino acid sequences of the S1 protein gene of the twenty-six IBV isolates were assembled, aligned, and compared with reference IBV strains using the MEGALIGN program in DNAStar. Phylogenetic analysis of the nucleotide sequences and the deduced amino acid sequences of the $\mathrm{S} 1$ protein gene was performed by the Clustal $\mathrm{V}$ method using DNAStar software [18]. Thirty-one reference strains were selected for molecular 
Table 2. Spike glycoprotein cleavage recognition sites and accession number of IBV isolates in China

\begin{tabular}{|c|c|c|c|}
\hline IBV isolates & Oligonucleotides $^{\mathrm{a}}$ & $\begin{array}{l}\text { Spike glycoprotein cleavage } \\
\text { recognition sites }{ }^{b}\end{array}$ & $\begin{array}{l}\text { Accession } \\
\text { number }\end{array}$ \\
\hline CK/CH/LTJ/95I & S1Oligo5' + IBV-212 & Arg-Arg-Phe-Arg-Arg & DQ167151 \\
\hline CK/CH/LHLJ/95I & S1Oligo5' + IBV-212 & His-Arg-Arg-Arg-Arg & DQ167141 \\
\hline CK/CH/LSC/95I & S1Oligo5' + IBV-212 & Arg-Arg-Phe-Arg-Arg & DQ167146 \\
\hline CK/CH/LHB/96I & S1Oligo5' + IBV-212 & His-Arg-Arg-Arg-Arg & DQ167137 \\
\hline $\mathrm{CK} / \mathrm{CH} / \mathrm{LGD} / 96 \mathrm{I}$ & S1Oligo5' + IBV-212 & His-Arg-Arg-Arg-Arg & DQ167136 \\
\hline $\mathrm{CK} / \mathrm{CH} / \mathrm{LDL} / 97 \mathrm{I}$ & IBV-87+ S1Oligo3' & Arg-Arg-Thr-Gly-Arg & DQ068701 \\
\hline CK/CH/LLN/98I & S1Oligo5' + IBV-212 & His-Arg-Arg-Arg-Arg & DQ167145 \\
\hline CK/CH/LDL/98I & IBV-87+ S1Oligo3' & Arg-Arg-Thr-Gly-Arg & DQ167132 \\
\hline CK/CH/LHLJ/99I & S1Oligo5' + IBV-212 & His-Arg-Arg-Arg-Arg & DQ167142 \\
\hline CK/CH/LSC/99I & S1Oligo5' + IBV-212 & Arg-Arg-Phe-Arg-Arg & DQ167147 \\
\hline $\mathrm{CK} / \mathrm{CH} / \mathrm{LAH} / 99 \mathrm{I}$ & S1Oligo5' + IBV-212 & Arg-Arg-His-Arg-Arg & DQ167129 \\
\hline $\mathrm{CK} / \mathrm{CH} / \mathrm{LHN} / 00 \mathrm{I}$ & S1Oligo5' + IBV-212 & Arg-Arg-Ser-Arg-Arg & DQ167143 \\
\hline $\mathrm{CK} / \mathrm{CH} / \mathrm{LDL} / 01 \mathrm{I}$ & IBV-87+ S1Oligo3' & Arg-Arg-Thr-Gly-Arg & DQ167130 \\
\hline $\mathrm{CK} / \mathrm{CH} / \mathrm{LXJ} / 02 \mathrm{I}$ & S1Oligo5' + IBV-212 & His-Arg-Arg-Arg-Arg & DQ167152 \\
\hline $\mathrm{CK} / \mathrm{CH} / \mathrm{LHLJ} / 02 \mathrm{I}$ & S1Oligo5' + S1Oligo3' & His-Arg-Arg-Arg-Arg & DQ167138 \\
\hline CK/CH/LSHH/03I & S1Uni2 + S1Oligo3 ${ }^{\prime}$ & His-Arg-His-Arg-Arg & DQ167149 \\
\hline CK/CH/LSHH/03II & S1Uni2 + S1Oligo3' & His-Arg-His-Arg-Arg & DQ167150 \\
\hline CK/CH/LGD/03I & S1Oligo5' + IBV-212 & Arg-Arg-Phe-Arg-Arg & DQ167133 \\
\hline $\mathrm{CK} / \mathrm{CH} / \mathrm{LAH} / 03 \mathrm{I}$ & S1Oligo5' + IBV-212 & Arg-Arg-His-Ser-Arg & DQ167128 \\
\hline $\mathrm{CK} / \mathrm{CH} / \mathrm{LSD} / 03 \mathrm{I}$ & S1Oligo5' + IBV-212 & His-Arg-Arg-Arg-Arg & DQ167148 \\
\hline CK/CH/LJL/04I & S1Oligo5' + IBV-212 & His-Arg-Arg-Arg-Arg & DQ167144 \\
\hline $\mathrm{CK} / \mathrm{CH} / \mathrm{LHLJ} / 04 \mathrm{~V}$ & S1Oligo5' + IBV-212 & His-Arg-Arg-Arg-Arg & DQ167139 \\
\hline CK/CH/LDL/04II & S1Oligo5' + IBV-212 & Arg-Arg-Tyr-Arg-Arg & DQ167131 \\
\hline CK/CH/LGD/04II & S1Oligo5' + IBV-212 & Arg-Arg-Phe-Arg-Arg & DQ167134 \\
\hline CK/CH/LGD/04III & S1Oligo5' + IBV-212 & Arg-Arg-Leu-Arg-Arg & DQ167135 \\
\hline CK/CH/LHLJ/04XI & S1Oligo5' + IBV-212 & His-Arg-Arg-Arg-Arg & DQ167140 \\
\hline
\end{tabular}

${ }^{a}$ Oligonucleotides used for amplifying $\mathrm{S} 1$ protein gene

${ }^{\mathrm{b}}$ Arg arginine, Phe phenylalanine, His histidine, Thr threonine, Gly glycine, Ser serine, Tyr tyrosine, Leu leucine

analysis. Of these, twenty-six were Chinese IBV strains from the GenBank database, and they represented most of the Chinese IBV field isolates available through GenBank or other publications.

A total of fifty-two Chinese IBV field isolates, including our twenty-six isolates, were chosen to give a representation based on geographic distribution, year of isolation, and phylogenetic position. In addition, two IBV strains, 3051/02 and T07/02, representing TW I and TW II IBV isolates in Taiwan [20], were selected. A Korean IBV isolate, K069-01, was also selected. This IBV strain belonged to genotype III of Korean IBV strains, and this genotype was a major type of IBV in Korea. JP8127, a Japanese IBV strain, was also selected, and its S1 protein gene was compared with Chinese IBV isolates. IBV strains from the above 3 geographically different areas were selected because we were interested in knowing whether the IBV isolates in China were introduced from neighboring countries and continents or whether they arose by mutations of circulating Chinese IBV strains. Furthermore, the S1 
protein gene of the H120 vaccine strain was selected and compared in this study because the vaccine was widely used for many years on poultry farms in China. The entire coding region of the $\mathrm{S} 1$ protein gene of these strains was chosen for analysis.

Table 3. Data for reference IBV strains and sequences

\begin{tabular}{|c|c|c|c|c|}
\hline $\begin{array}{l}\text { IBV strains } \\
\text { (origin) }\end{array}$ & $\begin{array}{l}\text { Years of } \\
\text { isolation }\end{array}$ & $\begin{array}{l}\text { Genotype/Pathogenicity } \\
\text { type }\end{array}$ & $\begin{array}{l}\text { Spike glycoprotein } \\
\text { cleavage recognition } \\
\text { sites }\end{array}$ & $\begin{array}{l}\text { Accession } \\
\text { number }\end{array}$ \\
\hline HBN (China) & $\begin{array}{l}\text { Between } 1996 \\
\text { and } 1998\end{array}$ & nepphropathogenicity & His-Arg-Arg-Arg-Arg ${ }^{\mathrm{a}}$ & DQ070837 \\
\hline QXIBV (China) & 1997 & proventriculus & His-Arg-Arg-Arg-Arg & AF193423 \\
\hline A2 (China) & After 2000 & $\mathrm{nd}^{\mathrm{b}}$ & His-Arg-Arg-Arg-Arg & AY043312 \\
\hline LX4 (China) & 1999 & nepphropathogenicity & His-Arg-Arg-Arg-Arg & AY189157 \\
\hline BJ (China) & 1998 & nd & Arg-Arg-Thr-Arg-Arg & AY319651 \\
\hline BJY (China) & $\begin{array}{l}\text { Between } 1996 \\
\text { and } 1998\end{array}$ & nepphropathogenicity & Arg-Arg-Thr-Arg-Arg & DQ070836 \\
\hline BJS (China) & $\begin{array}{l}\text { Between } 1996 \\
\text { and } 1998\end{array}$ & nepphropathogenicity & His-Arg-Thr-Lys-Arg & DQ070838 \\
\hline $\begin{array}{l}\text { tl/CH/LDT3/03 } \\
\text { (China) }\end{array}$ & 2003 & nepphropathogenicity & Arg-Arg-Phe-Arg-Arg & AY702975 \\
\hline JX/99/01 (China) & 1999 & nd & Arg-Arg-His-Arg-Arg & AF210735 \\
\hline BJQ (China) & $\begin{array}{l}\text { Between } 1996 \\
\text { and } 1998\end{array}$ & nepphropathogenicity & Arg-Arg-Phe-Arg-Arg & DQ070839 \\
\hline TJ/96/02 (China) & 1996 & nd & Arg-Arg-Phe-Arg-Arg & AF257075 \\
\hline SH2 (China) & 2005 & nepphropathogenicity & Arg-Arg-Phe-Arg-Arg & DQ075324 \\
\hline $\mathrm{J}$ (China) & 1998 & nepphropathogenicity & Arg-Arg-Phe-Arg-Arg & AF352312 \\
\hline SC021202 (China) & 2002 & nepphropathogenicity & Arg-Arg-His-Arg-Arg & AY237817 \\
\hline HaN1-95 (China) & 1995 & nd & Arg-Arg-Phe-Arg-Arg & AY251817 \\
\hline W93 (China) & 1993 & nepphropathogenicity & Arg-Arg-Phe-Arg-Arg & AY427818 \\
\hline D41 (China) & 1987 & nepphropathogenicity & Arg-Arg-Phe-Arg-Arg & AF036937 \\
\hline SD/97/01 (China) & 1997 & nd 1 & Arg-Arg-Phe-Arg-Arg & AF208240 \\
\hline 2/97 (China) & 1997 & proventriculus & Arg-Arg-Phe-Arg-Arg & AY043218 \\
\hline ZJ971 (China) & 1997 & proventriculus & Arg-Arg-Phe-Arg-Arg & AF352313 \\
\hline 1/98 (China) & 1998 & proventriculus & Arg-Arg-Phe-Arg-Arg & AY043220 \\
\hline JL/97/01 (China) & 1997 & nd & Arg-Arg-Phe-Arg-Arg & AF258780 \\
\hline JS/95/03 (China) & 1995 & nd & Arg-Arg-Phe-Arg-Arg & AF208239 \\
\hline SDA (China) & After 2000 & nd & Arg-Arg-Phe-Arg-Arg & AY043313 \\
\hline HN99 (China) & 1999 & nepphropathogenicity & Arg-Arg-Ser-Arg-Arg & AY775551 \\
\hline J2 (China) & $\begin{array}{l}\text { Between } 1996 \\
\text { and } 1998\end{array}$ & proventriculus & Arg-Arg-Thr-Gly-Arg & AF286303 \\
\hline K069-01 (Korea) & 2001 & Korean Genotype III & Arg-Arg-Phe-Arg-Arg & AY257061 \\
\hline JP8127 (Japan) & 1993 & $\begin{array}{l}\text { Closely related to Australia } \\
\text { classical strains }\end{array}$ & Arg-Arg-Phe-Lys-Arg & AY296744 \\
\hline 3051/02 (Taiwan) & 2002 & TW I & Arg-Arg-Phe-Arg-Arg & AY606318 \\
\hline T07/02 (Taiwan) & 2002 & TW II & Arg-Arg-Phe-Arg-Arg & AY606322 \\
\hline $\mathrm{H} 120$ & Vaccine strain & Mass serotype & Arg-Arg-Phe-Arg-Arg & M21970 \\
\hline
\end{tabular}

${ }^{\mathrm{a}}$ His histidine, Arg arginine, Thr threonine, Lys lysine, Phe phenylalanine, Ser serine, Gly glycine

$\mathrm{b}_{n d \text { not documented }}$ 


\section{Strains and accession numbers used for molecular analysis}

The fifty-seven IBV strains, including our twenty-six isolates, were molecularly analyzed. The twenty-six IBV isolates in this study and their accession numbers are listed in Table 2. The IBV reference strains and their accession numbers are listed in Table 3.

\section{Results}

\section{Detection of IBV}

Twenty-six IBV strains were isolated from flocks that were suspected of IBV infection. The isolates were from flocks in different parts of China (Fig. 1) that showed clinical IB and had 5 to $60 \%$ mortality. The nephritis observed in all flocks was characterized by enlarged and pale kidneys, frequently with urate deposits in the tubules, and severe dehydration and weight loss. Typical signs, including dwarfing and death of the embryo, were observed in different passages when each isolate was inoculated into embryos (Table 1). Diagnoses based on electron microscopy examination showed all isolates had typical coronavirus morphology and were free of other agents such as Newcastle disease virus (NDV) (results not shown).

\section{Phylogenetic analysis}

To assess the genetic relatedness among the IBV strains, a phylogenetic tree was performed with S1 protein genes. The results are shown in Fig. 2. The fiftyseven IBV strains were separated into seven genotypes (I to VII) by phylogenetic analysis of the S1 protein genes (Fig. 2). Genotype I consisted of fourteen Chinese strains having small evolutionary distances from each other as shown in the rooted tree (Fig. 2). Genotype II included 6 strains that were isolated in the 1990s in China. Most of the Chinese IBV isolates included in genotype III were also isolated in the 1990s, except t1/CH/LDT3/03 and CK/CH/LGD/03I, which were both isolated in Guangdong province in 2003 from teal [29] and layer hens, respectively. The Korean IBV isolate, K069-01, which belonged to genotype III of Korean IBV strains [27], was closely related to those isolates in genotype III. Six of eight IBV isolates displayed in genotype IV were isolated after 2000, and most of them came from southern China. Furthermore, isolates included in genotype IV showed larger evolutionary distances (Fig. 2). Ten Chinese IBV isolates formed the genotype $\mathrm{V}$ in which $\mathrm{H} 120$ was included, and none of our twenty-six isolates were grouped under this genotype. The isolates HN99 and $\mathrm{CK} / \mathrm{CH} / \mathrm{LHN} / 00 \mathrm{I}$, both isolated in Henan province in 1999 and 2000, respectively, together with a Japanese isolate, JP8127, were grouped into genotype VI. Our three IBV isolates recovered in Dalian, China, between 1997 and 2001, were grouped into genotype VII. A Chinese IBV isolate, J2, which was isolated from the proventricular tissues of infected chickens [46], was also placed in genotype VII. Two IBV isolates, 3051/02 and T07/02, belonging to TW I and TW II, formed a unique genotype. 


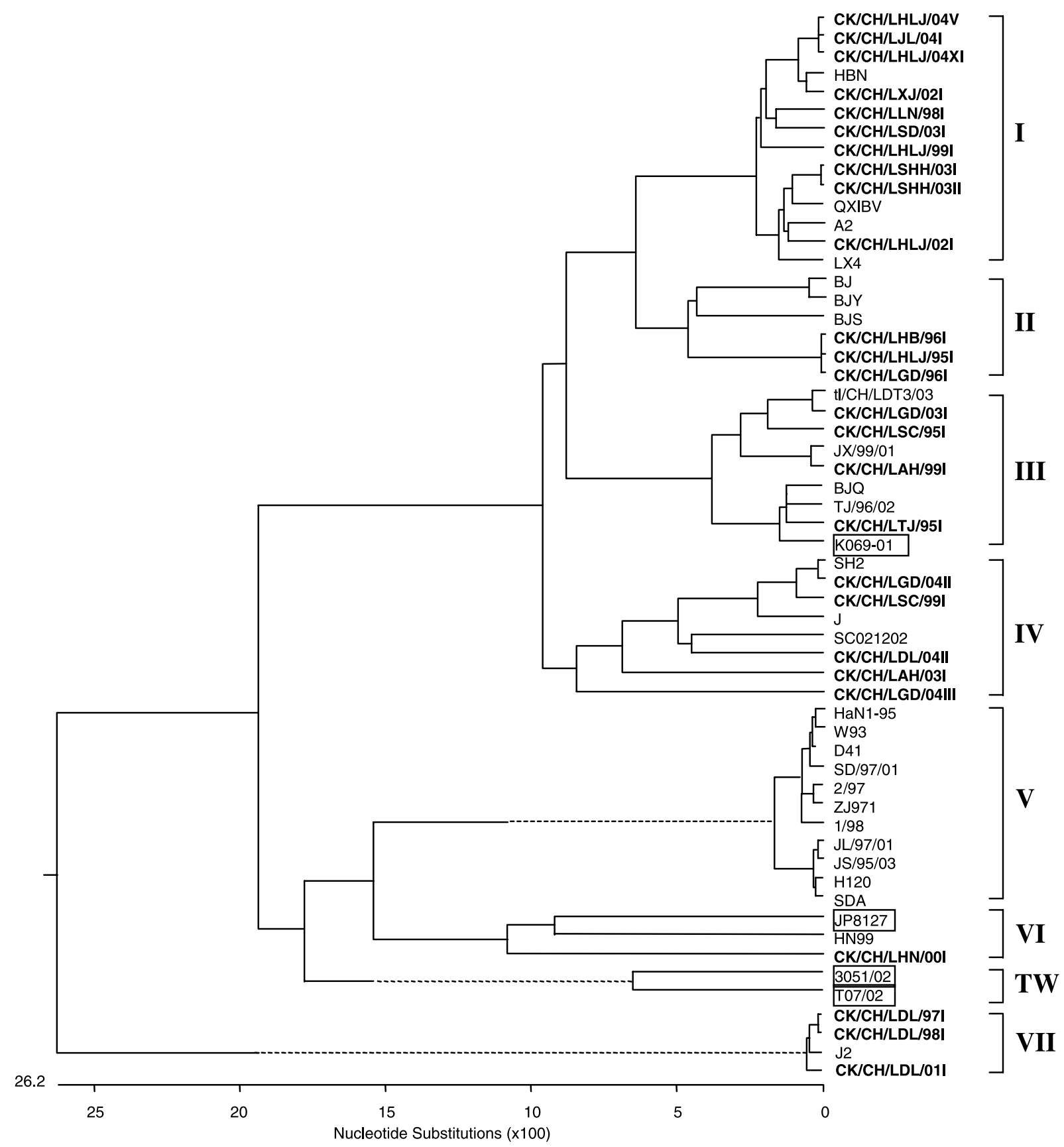

Fig. 2. Phylogenetic relationships, based on the sequence of the $S 1$ subunit of the $S$ protein gene, of our twenty-six isolates and thirty-one reference strains (the first $1669 \mathrm{nt}$, starting at the AUG translation initiation codon, of the S protein genes) using the MEGALIGN program

DNAStar with the Clustal V method [18]. Our IBV isolates are in bold type

\section{The spike glycoprotein cleavage recognition site}

The spike glycoprotein of IBV is translated as a precursor protein (S0) and then cleaved into two subunits S1 and S2 [9, 24]. Cleavage site motifs of the fifty-seven 
IBV strains are listed in Table 2 and Table 3, and twelve different cleavage site sequences were observed. The most common cleavage recognition site observed ( 24 of 57 viruses) was Arg-Arg-Phe-Arg-Arg. Viruses with this cleavage recognition site are the H120 vaccine strain, one Korean strain, K069-01, Taiwan isolates 3015/ 02 and T07/02, ten Chinese Mass-type isolates, and ten other Chinese isolates included in genotype III (six strains) and IV (four strains). The second most common site was His-Arg-Arg-Arg-Arg. Viruses with this cleavage recognition site include twelve isolates in genotype I and three in genotype II. This recognition site was unique for virus isolates in China. The third most common site was ArgArg-Thr-Gly-Arg. Viruses with this cleavage recognition site were placed in genotype VII, which included our three isolates (CK/CH/LDL/97I, CK/CH/LDL/98I, and $\mathrm{CK} / \mathrm{CH} / \mathrm{LDL} / 01 \mathrm{I}$ ) and isolate $\mathrm{J} 2$. This cleavage recognition site was also unique to viruses in China. The JX/99/01, CK/CH/LAH/99I, and SC021202 viruses had a cleavage recognition site, Arg-Arg-His-Arg-Arg, as did D1466 [22]. Chinese IBV isolates HN99 and CK/CH/LHN/00I, which were grouped in genotype VI, had a cleavage recognition site, Arg-Arg-Ser-Arg-Arg, which was the most common site reported by Jackwood [22], who had compared the cleavage recognition sites of fifty-five IBV isolates to determine if the site sequence correlates with host cell range, serotype, geographic origin, and pathogenicity. The $\mathrm{CK} / \mathrm{CH} / \mathrm{LSHH} / 03 \mathrm{I}$ and $\mathrm{CK} / \mathrm{CH} / \mathrm{LSHH} / 03 \mathrm{II}$ viruses had a unique cleavage recognition site, His-Arg-His-Arg-Arg, as did isolates BJ and BJY, Arg-Arg-ThrArg-Arg, CK/CH/LAH/03I, Arg-Arg-His-Ser-Arg, CK/CH/LDL/04II, Arg-ArgTyr-Arg-Arg, CK/CH/LGD/04III, Arg-Arg-Leu-Arg-Arg, BJS, His-Arg-Thr-LysArg, and Japanese Strain, JP8127, Arg-Arg-Phe-Lys-Arg.

\section{Amino acid sequence comparison}

The complete nucleotide and predicted amino acid sequences of the S1 protein of the fifty-seven IBV strains were determined and compared. Except for isolates in genotype V, which included the Mass-type strains, none of the Chinese IBV isolates examined in this study shared more than $83 \%$ amino acid similarity in the $\mathrm{S} 1$ protein with the $\mathrm{H} 120$ vaccine strain. The $\mathrm{S} 1$ protein genes, which varied from 0.2 to $26.7 \%$ among the strains examined, indicated that point mutations, deletions, and insertions contribute to the evolution of IBV. IBVs in same genotypes showed more than $90 \%$ amino acid sequence similarities, whereas most of the viruses in different genotypes showed less than $90 \%$, with the exceptions of isolate BJS (genotype II) and isolates in genotype IV, BJQ (genotype III) and isolates in genotype $\mathrm{V}$, isolates between genotypes I and III, which showed amino acid similarities of $91-94.5 \%, 90.5-92 \%$, and $93.2-95.6 \%$, respectively. The overall predicted amino acid sequence comparisons of the entire S1 protein of fifty-seven IBV strains reflected that most of the sequence variations were concentrated in three regions. The first included residues 50-87, corresponding to the S1 protein of the H120 vaccine strain, in which the hypervariable region 1 (HVR1) is located $[8,37,42]$. The second contained amino acid sequences between residues 114-140, which encompasses the hypervariable region 2 (HVR2) [8, 37, 42]. The last included residues 273-293, in which the hypervariable region 3 (HVR3) 
Table 4. Deletions and insertions of the predicted amino acids of the S1 protein of Chinese IBV isolates compared with the H120 vaccine strain ${ }^{\mathrm{a}}$

\begin{tabular}{|c|c|c|c|c|c|c|c|c|c|c|c|}
\hline \multirow[t]{2}{*}{ Strains } & \multicolumn{6}{|c|}{ Deletions or substitutions ${ }^{\mathrm{b}}$} & \multicolumn{4}{|c|}{ Insertions ${ }^{c}$} & \multirow[t]{2}{*}{ Genotype } \\
\hline & 24 & 25 & $58-60$ & $117-118$ & $25-26$ & $72-73$ & $116-117$ & $137-138$ & $140-141$ & 283-284 & \\
\hline $\mathrm{H} 120$ & $\mathrm{~S}$ & $\mathrm{~S}$ & NNA & $\mathrm{HV}$ & - & $\ldots$ & -- & - & $\cdots$ & - & $\mathrm{V}$ \\
\hline $\mathrm{CK} / \mathrm{CH} / \mathrm{LHLJ} / 04 \mathrm{~V}$ & $\mathrm{D}$ & $\mathrm{N}$ & SNA & AG & $\mathrm{N}$ & $-\ldots$ & SG & - & -... & - & I \\
\hline CK/CH/LJL/04I & $\mathrm{D}$ & $\mathrm{N}$ & NNA & AG & $\mathrm{N}$ & - n & SG & - & $\ldots$ & - & I \\
\hline CK/CH/LHLJ04XI & $\mathrm{D}$ & $\mathrm{N}$ & NNA & AG & $\mathrm{N}$ & $\ldots$ & SG & - & $-\ldots$ & - & I \\
\hline HBN & $\mathrm{D}$ & $\mathrm{N}$ & NNA & AG & $\mathrm{N}$ & $\ldots$ & SG & - & $-\ldots$ & - & I \\
\hline $\mathrm{CK} / \mathrm{CH} / \mathrm{LXJ} / 02 \mathrm{I}$ & $\mathrm{D}$ & $\mathrm{N}$ & NNA & AG & $\mathrm{N}$ & $\ldots \ldots$ & SG & - & $\ldots$ & - & I \\
\hline CK/CH/LLN/98I & $\mathrm{D}$ & $\mathrm{N}$ & NNA & SG & $\mathrm{N}$ & $\ldots \ldots$ & SG & - & $\ldots$ & - & I \\
\hline $\mathrm{CK} / \mathrm{CH} / \mathrm{LSD} / 03 \mathrm{I}$ & $\mathrm{D}$ & $\mathrm{N}$ & NNA & SG & $\mathrm{N}$ & $-\ldots$ & SG & - & $\ldots$ & - & I \\
\hline CK/CH/LHLJ/99I & G & $\mathrm{S}$ & NNA & AG & - & - n- & SG & - & $\ldots$ & - & I \\
\hline CK/CH/LSHH/03I & A & $\mathrm{N}$ & -.- & SG & $\mathrm{N}$ & $-\ldots$ & SG & - & $\ldots$ & - & I \\
\hline CK/CH/LSHH/03II & A & $\mathrm{N}$ & --- & SG & $\mathrm{N}$ & $-\ldots$ & SG & - & $-\ldots$ & - & I \\
\hline QXIBV & A & $\mathrm{N}$ & NNA & SG & $\mathrm{N}$ & $\ldots$ & SG & - & $\ldots$ & - & I \\
\hline $\mathrm{A} 2$ & A & $\mathrm{N}$ & NNA & TG & $\mathrm{N}$ & $\ldots \ldots$ & SG & - & $\ldots$ & - & I \\
\hline $\mathrm{CK} / \mathrm{CH} / \mathrm{LHLJ} / 02 \mathrm{I}$ & G & $\mathrm{N}$ & SNA & PT & - & $-\ldots$ & SG & - & -... & - & I \\
\hline LX4 & A & $\mathrm{N}$ & NNA & SG & - & $\ldots$ & SG & - & $\ldots$ & - & I \\
\hline BJ & G & $\mathrm{N}$ & NNA & -- & - & YTNGNSDV & $\mathrm{N}-$ & - & $-\ldots$ & - & II \\
\hline BJY & $\mathrm{G}$ & $\mathrm{N}$ & NNA & - & - & YANGNSDV & N- & - & $\ldots$ & - & II \\
\hline BJS & G & $\mathrm{S}$ & NNA & -- & - & YSNG-IDV & $\mathrm{N}-$ & - & $\ldots$ & - & II \\
\hline $\mathrm{CK} / \mathrm{CH} / \mathrm{LHB} / 96 \mathrm{I}$ & $\mathrm{D}$ & $-d$ & NNA & -- & - & YNNGNSDV & $\mathrm{K}-$ & - & $\ldots$ & - & II \\
\hline CK/CH/LHLJ/95I & $\mathrm{D}$ & - & NNA & - & - & YNNGNSDV & $\mathrm{K}-$ & - & -... & - & II \\
\hline CK/CH/LGD/96I & $\mathrm{D}$ & - & NNA & -- & - & YNNGNSDV & $\mathrm{K}-$ & - & $\ldots$ & - & II \\
\hline t1/CH/LDT3/03 & A & $\mathrm{N}$ & NNA & SG & $\mathrm{N}$ & $\ldots$ & SG & - & $\ldots$ & - & III \\
\hline CK/CH/LGD/03I & A & $\mathrm{N}$ & NNA & SG & $\mathrm{N}$ & $\cdots$ & SG & - & $-\cdots$ & - & III \\
\hline CK/CH/LSC/95I & $\mathrm{D}$ & $\mathrm{N}$ & NNA & SG & $\mathrm{N}$ & $\ldots$ & SG & - & $\ldots$ & - & III \\
\hline JX/99/01 & - & $\mathrm{H}$ & NNA & SG & $\mathrm{N}$ & $\ldots$ & SG & - & $\ldots$ & - & III \\
\hline CK/CH/LAH/99I & - & $\mathrm{H}$ & NNA & SG & $\mathrm{N}$ & - . . & SG & - & -... & - & III \\
\hline BJQ & - & $\mathrm{G}$ & NNA & SG & $\mathrm{N}$ & $\ldots$ & SG & - & $\ldots$ & - & III \\
\hline $\mathrm{TJ} / 96 / 02$ & - & $\mathrm{N}$ & NNA & SG & $\mathrm{S}$ & - . & SG & - & - . - & - & III \\
\hline $\mathrm{CK} / \mathrm{CH} / \mathrm{LTJ} / 95 \mathrm{I}$ & - & $\mathrm{S}$ & NNA & SG & $\mathrm{N}$ & - - - - & SG & - & $\ldots$ & - & III \\
\hline K069-01 & - & $\mathrm{N}$ & NNA & SG & $\mathrm{N}$ & $\ldots$ & RG & - & $\ldots$ & - & III \\
\hline $\mathrm{SH} 2$ & $\mathrm{D}$ & - & NNA & -- & - & YTNG-NDV & $\mathrm{N}-$ & - & $\ldots$ & - & IV \\
\hline $\mathrm{CK} / \mathrm{CH} / \mathrm{LGD} / 04 \mathrm{II}$ & $\mathrm{D}$ & - & NNA & - & - & YTNG-NDV & $\mathrm{N}-$ & - & -..- & - & IV \\
\hline CK/CH/LSC/99I & $\mathrm{D}$ & - & NNA & -- & - & YTNG-NDV & $\mathrm{N}-$ & - & $\ldots$ & - & IV \\
\hline $\mathrm{J}$ & $\mathrm{D}$ & $\mathrm{N}$ & NNA & -- & - & YTNG-KDV & N- & - & $\ldots$ & - & IV \\
\hline SC021202 & $\mathrm{D}$ & $\mathrm{N}$ & NNA & -- & - & YTNG-NDV & N- & - & $\ldots$ & - & IV \\
\hline $\mathrm{CK} / \mathrm{CH} / \mathrm{LDL} / 04 \mathrm{II}$ & $\mathrm{G}$ & $\mathrm{N}$ & NNA & -- & $\mathrm{N}$ & YSNG-NDV & P- & - & $\ldots$ & - & IV \\
\hline CK/CH/LAH/03I & $\mathrm{N}$ & - & NNA & -- & - & YANG-NHA & $\mathrm{N}-$ & - & $-\ldots$ & $\mathrm{L}$ & IV \\
\hline CK/CH/LGD/04III & $\mathrm{H}$ & $\mathrm{D}$ & NNA & -- & - & YSNG-NDV & $\mathrm{N}-$ & - & $\ldots$ & - & IV \\
\hline HaN1-95 & $\mathrm{S}$ & $\mathrm{S}$ & NNA & QG & - & $\ldots$ & -- & - & $\ldots$ & - & $\mathrm{V}$ \\
\hline W93 & $\mathrm{S}$ & $\mathrm{S}$ & NNA & QG & - & $-\ldots$ & -- & - & $-\cdots$ & - & V \\
\hline D41 & S & S & NNA & QG & - & - . & -- & - & $\ldots$ & - & $\mathrm{V}$ \\
\hline $\mathrm{SD} / 97 / 01$ & $\mathrm{~S}$ & $\mathrm{~S}$ & NNA & $\mathrm{HV}$ & - & $\ldots$ & -- & - & $\ldots$ & - & V \\
\hline 2/97 & $\mathrm{S}$ & $\mathrm{S}$ & NNA & $\mathrm{HV}$ & - & $-\ldots$ & -- & - & $-\cdots$ & - & $\mathrm{V}$ \\
\hline ZJ971 & S & S & NNA & $\mathrm{HV}$ & - & - _ _ - _ & -- & - & $\ldots$ & - & $\mathrm{V}$ \\
\hline $1 / 98$ & $\mathrm{~S}$ & $\mathrm{~S}$ & NNA & $\mathrm{HV}$ & - & $\ldots$ & -- & - & $\ldots$ & - & $\mathrm{V}$ \\
\hline JL/97/01 & S & S & NNA & YD & - & - - - & - & - & $\ldots$ & - & $\mathrm{V}$ \\
\hline $\mathrm{JS} / 95 / 03$ & S & S & NNA & YD & - & - . & -- & - & - . - & - & $\mathrm{V}$ \\
\hline SDA & $\mathrm{S}$ & $\mathrm{S}$ & NNA & YD & - & $\ldots$ & -- & - & $\ldots$ & - & $\mathrm{V}$ \\
\hline JP8127 & D & $\mathrm{T}$ & NNA & $\mathrm{NN}$ & - & $\cdots-$ & SG & Q & GPAD & $\mathrm{T}$ & VI \\
\hline HN99 & G & $\mathrm{N}$ & SNA & AG & - & - & SG & Q & GPSD & - & VI \\
\hline $\mathrm{CK} / \mathrm{CH} / \mathrm{LHN} / 00 \mathrm{I}$ & $\mathrm{E}$ & $\mathrm{S}$ & NNA & SN & - & $\ldots$ & SG & $\mathrm{H}$ & MPGH & - & VI \\
\hline $3051 / 02$ & $\mathrm{D}$ & $\mathrm{T}$ & NNA & SG & - & - - - - - & SG & - & $\ldots$ & - & TW \\
\hline $\mathrm{T} 07 / 02$ & $\mathrm{D}$ & $\mathrm{T}$ & ANA & QG & - & $\ldots$ & ST & - & $\ldots$ & - & TW \\
\hline $\mathrm{CK} / \mathrm{CH} / \mathrm{LDL} / 97 \mathrm{I}$ & $\mathrm{N}$ & $\mathrm{E}$ & NNA & DG & - & $\ldots$ & HG & $\mathrm{K}$ & $\ldots$ & - & VII \\
\hline $\mathrm{CK} / \mathrm{CH} / \mathrm{LDL} / 98 \mathrm{I}$ & $\mathrm{N}$ & $\mathrm{E}$ & NNA & NG & - & $\cdots-$ & HG & $\mathrm{K}$ & $\cdots$ & - & VII \\
\hline $\mathrm{J} 2$ & $\mathrm{~N}$ & $\mathrm{E}$ & NNA & NG & - & $\ldots$ & HG & $\mathrm{K}$ & $\ldots$ & - & VII \\
\hline $\mathrm{CK} / \mathrm{CH} / \mathrm{LDL} / 01 \mathrm{I}$ & $\mathrm{N}$ & $\mathrm{E}$ & NNA & NG & - & 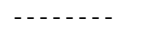 & HG & $\mathrm{K}$ & $-\cdots$ & - & VII \\
\hline
\end{tabular}

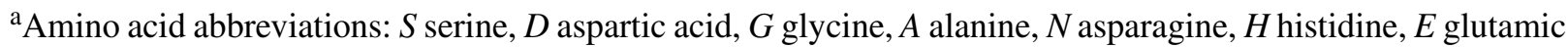
acid, $T$ threonine, $Y$ tyrosine, $P$ proline, $Q$ glutamine, $V$ valine, $I$ isoleucine, $K$ lysine, $R$ arginine, $M$ methionine; ${ }^{b}$ positions of residues in deduced amino acid sequences of the $S 1$ protein of the H120 vaccine strain; ${ }^{c}$ positions of residues in deduced amino acid sequences of the S1 protein of the H120 vaccine strain between which the residue(s) of other IBVs was (were) inserted; ${ }^{\mathrm{d}}$ missing amino acid residues 
is present [39]. Furthermore, almost all of the Chinese IBV isolates contained deletions and insertions except for those of the Mass-type IBV, which were included in genotype $\mathrm{V}$ in this study, and had amino acid sequences similar to those of the H120 strain (Table 4). The deletions and insertions, which occurred in the predicted amino acid sequences of the S1 proteins of fifty-seven IBV strains in this study, were correlated with the genotypes of S1 protein genes, as shown in Table 4. In addition, the Korean strain, K069-01, shared most of the motifs of deletions and insertions with Chinese IBV field isolates in genotype III.

\section{Discussion}

In 1962, Winterfield and Hitchner reported a nephrosis condition associated with IB in the United States, and Cumming reported an IB outbreak causing severe kidney lesion in chickens in Australia [13, 43]. Since this time, various nephropathogenic strains of IBV have been identified throughout the world [33]. In China, IB with nephritis was first reported in 1982 and several nephropathogenic IBV strains have been isolated in different parts of China since then [31, 32, 44]. Of the twenty-six IBV isolates in this study, one was isolated from atrophic oviduct of a diseased layer hen, six from swollen proventricular tissues of infected chickens, and the rest from swollen kidneys of IB-suspected chickens. Although seven IBV strains were isolated from tissues other than kidney, the gross lesions of kidney in these diseased chickens were also obvious. Based on the fact that these IBV strains were isolated from 1995 to 2004 in China, we considered that IB was prevalent all the while in China, although vaccines based on Mass-type strains such as H120 and H52 have been used for many years on poultry farms, and nephropathogenic IBV was the major type of IBV circulating in China.

Although the genetic basis of IBV pathogenicity is not known, the S1 protein gene of IBV has serotype-specific and neutralization-specific epitopes, and serotypic evolution and the genetic diversity of IBV is mainly monitored by analysis of the $\mathrm{S} 1$ gene $[2,9,10,23,27,32,42]$. In the present study, phylogenetic analysis of S1 genes showed that Chinese IBV isolates were grouped into seven genotypes (Fig. 2). IBVs isolated ten years ago were included in the same genotype with the strains isolated recently (for example, $\mathrm{CK} / \mathrm{CH} / \mathrm{LSC} / 95 \mathrm{I}$ and $\mathrm{CK} / \mathrm{CH} /$ LGD/03I in genotype III), indicating that this genotype may be indigenous and has been prevalent in China for at least ten years. Serotype differences among the genetically distinct IBVs generally correlated with variations in the HVR of the S1 protein gene $[4,8]$ and differences of as little as $5 \%$ between $\mathrm{S} 1$ sequences of IBV could result in poor cross-protection offered by currently used vaccines [19]. The low identities $(<83 \%)$ of amino acid sequences between Chinese IBV isolates and H120, except for those of the Mass-type IBV, which were included in genotype V in this study, may account for the prevalence of the viruses during the past ten years in spite of the extensive use of Mass-type vaccines in the field in China. Hence, developing vaccines from local strains is necessary for IBV control in China.

Although the number of basic residues around the spike glycoprotein cleavage recognition site of IBV does not appear to correlate with increased cleavability, 
host cell range, and increased virulence as it does with the envelope glycoproteins of orthomyxoviruses and paramyxoviruses, the sequences of cleavage recognition sites was correlated with geographic distribution of the viruses [22]. Nine spike glycoprotein cleavage recognition site sequences were found in viruses of genotypes I to IV, in which six were unique to isolates in China, indicating genetically distinct evolution from viruses in other countries by cleavage recognition site analysis. However, a Korean IBV strain, K069-01, shared the same cleavage recognition site sequence, Arg-Arg-Phe-Arg-Arg, with ten Chinese isolates included in subgenotypes III (six strains) and IV (four strains), ten Chinese Mass-type isolates (genotype V), and two Taiwan isolates, 3015/02 and T07/02. Furthermore, K069-01 and Chinese isolates in genotype III shared more than 90\% amino acid identities and they were also grouped into the same genotype (Fig. 2). K069-01 was clustered into genotype III of Korean IBV strains, which was the major type of IBV circulating in Korea, and isolates in this genotype induced 50\% mortality in 1-day-old chicks as well as severe renal urate deposition on the kidneys [40]. This was similar to Chinese isolates in genotype I [29, 31]. Based on these facts, IBVs between Chinese genotype III and Korean genotype III had a close relationship, as did NDV [26], owing to the increased trade of agricultural products including poultry between two countries. Unlike K069-01, isolates 3051/02 and T07/02, which represented TW I and TW II strains, respectively [20], were clustered into a separate branch that was separated from the Chinese genotypes, indicating that they had different origins.

Ten Chinese IBV strains were classified into the Mass serotype (genotype $\mathrm{V}$ by phylogenetic analysis). As in China, Mass-type IBVs were also present in other Asian countries, such as Korea [27, 40], Japan [32, 38], and Taiwan $[20,30]$, although Mass-type vaccines were commonly used in these countries or continents. However, Chinese Mass-type strains were all isolated in the 1990s and were not the major IBV type circulating in recent years in China. Molecular studies have shown that a new serotype or variant can emerge as a result of only a few changes in the amino acid composition in the $S 1$ part of the virus spike protein, with the majority of the virus genome remaining unchanged [6]. This could be due to immunologic pressure caused by the widespread use of vaccines, to recombination as a consequence of mixed infections, or to the decrease of dominant serotypes as a result of vaccination, allowing other field strains to emerge. To this study, the Mass-type viruses may have come from the vaccine strains by point mutation, although the possibility that some of them were reisolations of vaccine strains cannot be excluded.

Two strains, HN99 and CK/CH/LHN/00I, both isolated in Henan province in China, together with a Japanese strain, JP8127, constituted a "novel" genotype VI (Fig. 2). These two Chinese isolates did not show close similarity to any of the S1 protein sequences of other Chinese IBV isolates available through GenBank or publications. Interestingly, BLAST searches revealed significant similarity (99\%) of S1 protein genes between isolate HN99 and a vaccine strain, JAAS (AY839140), which was from Australia and used in China to control IBV. The isolate $\mathrm{CK} / \mathrm{CH} / \mathrm{LHN} / 00 \mathrm{I}$ shared $99 \%$ similarity in the $\mathrm{S} 1$ protein gene with another 
IBV vaccine strain, Jilin (AY839144), which was also used in China. When $\mathrm{CK} / \mathrm{CH} / \mathrm{LHN} / 00 \mathrm{I}$ was inoculated experimentally into 15-day-old SPF chickens, no disease signs were apparent (S. Liu et al., unpub. data). The spreading of a virus from one area or country to another could be due, at least in part, to its improper introduction by the trading of birds or by the use of attenuated vaccines. To our knowledge, no other IBV strains related to HN99 or CK/CH/LHNOOI were isolated in recent years in China, and considering the pathogenicity and genetically close relationship between the two isolates and the corresponding vaccine strains, we speculated that the two isolates would be reisolations of vaccine strains.

Isolate $\mathrm{J} 2$, which was very similar to $\mathrm{Q} 1$ and $\mathrm{T} 3$, was genetically distinct from most of the Chinese IBV isolates [45]. In this study, our three isolates (CK/CH/LDL/97I, CK/CH/LDL/98I, and CK/CH/LDL/01I) were clustered into the same group (genotype VII) with J2. Similar to J2, CK/CH/LDL/97I and $\mathrm{CK} / \mathrm{CH} / \mathrm{LDL} / 98 \mathrm{I}$ were isolated in swollen proventriculars tissues of infected chickens, whereas $\mathrm{CK} / \mathrm{CH} / \mathrm{LDL} / 01 \mathrm{I}$ was isolated from atrophic oviduct of a diseased layer hen. It was found that the gross lesions of the kidney in these diseased chickens were also obvious, as with isolate 2992/02 [20]. 2992/02 was isolated in Taiwan and was very similar to the $\mathrm{J} 2$ strain by comparison of $\mathrm{S} 1$ protein genes [20]. The diversity of the pathogenicity of IBV strains was expected; although the primary tissue of IBV infection is the respiratory tract, some isolates can grow in nonrespiratory organs such as the kidney, the female reproductive tract, intestine, and spleen of chickens $[2,14,33,36]$.

With the exception of the Massachusetts strain, a very interesting aspect of IBV epidemiology, as far as it is possible to know, is the presence and the spreading of the various IBV serotypes in different continents. About 20 emergent serotypes in North America did not spread to other continents. Similarly, the European, Australian, and Asiatic serotypes apparently did not spread elsewhere. In China, IBV epidemiology is more complicated. Besides genotypes I to IV and VII, the Mass-type IBV and IBV closely related to Australian classical strains were also present, indicating IBVs showing various genetic differences were cocirculating in China.

\section{Acknowledgements}

We would like to thank Dr. J. J. Giambrone, Department of Poultry Science, Auburn University, Auburn, U.S.A., for his helpful comments in reviewing the manuscript.

\section{References}

1. Adzhar A, Gough RE, Haydon D, Shaw K, Britton P, Cavanagh D (1997) Molecular analysis of the 793/B serotype infectious bronchitis virus in Great Britain. Avian Pathol 26: 625-640

2. Bayry J, Goudar MS, Nighot PK, Kshirsagar SG, Ladman BS, Gelb J Jr, Ghalsasi GR, Kolte GN (2005) Emergence of a nephropathogenic avian infectious bronchitis virus with a novel genotype in India. J Clin Microbiol 43: 916-918 
3. Boursnell MEG, Brown TDK, Foulds IJ, Green PF, Tomlet FM, Binns MM (1987) Completion of the sequence of the genome of the coronavirus avian infectious bronchitis virus. J Gen Virol 68: 57-77

4. Callison SA, Jackwood MW, Hilt DA (2001) Molecular characterization of infectious bronchitis virus isolates foreign to the United States and comparison with United States isolates. Avian Dis 45: 492-499

5. Cavanagh D (2003) Severe acute respiratory syndrome vaccine development: experiences of vaccination against avian infectious bronchitis coronavirus. Avian Pathol 32: 567-582

6. Cavanagh D, Davis PJ, Cook JKA (1992) Infectious bronchitis virus: evidence for recombination within the Massachusetts serotype. Avian Pathol 21: 401-408

7. Cavanagh D, Davis PJ, Darbyshire JH, Peters RW (1986) Coronavirus IBV: virus retaining spike glycopolypeptide $\mathrm{S} 2$ but not $\mathrm{S} 1$ is unable to induce virus-neutralizing or haemagglutination-inhibiting antibody, or induce chicken tracheal protection. J Gen Virol 67: 1435-1442

8. Cavanagh D, Davis PJ, Mockett AP (1988) Amino acids within hypervariable region 1 of avian coronavirus IBV (Massachusetts serotype) spike glycoprotein are associated with neutralization epitopes. Virus Res 11: 141-150

9. Cavanagh D, Davis PJ, Pappin DJ, Binns MM, Boursnell ME, Brown TDK (1986) Coronavirus IBV: partial amino terminal sequencing of spike polypeptide $\mathrm{S} 2$ identifies the sequence Arg-Arg-Phe-Arg-Arg at the cleavage site of the spike precursor propolypeptice of IBV strains Beaudette and M41. Virus Res 4: 133-143

10. Cavanagh D, Mawditt K, Welchman DdeB, Britton P, Gough RE (2001) Coronaviruses from pheasant (Phasianus colchicus) are genetically closely related to coronaviruses of domestic fowl (infectious bronchitis virus) and turkeys. Avian Pathol 31: 81-93

11. Cavanagh D, Naqi S (2003) Infectious bronchitis. In: Saif YM, Barnes HJ, Glisson JR, Fadly AM, McDougald LR, Swayne DE (eds) Diseases of poultry, 11th edn. Iowa State University Press. Ames, IA, pp 101-119

12. Clarke JK, McFerran JB, Gay FW (1972) Use of allantoic cells for the detection of avian infectious bronchitis virus. Arch Virol 36: 62-70

13. Cumming RB (1963) Infectious avian nephrosis (uraemia) in Australia. Aust Vet J 39: $145-147$

14. Dhinakar Raj G, Jones RC (1996) Protectotypic differentiation of avian infectious bronchitis viruses using an in vitro challenge model. Vet Microbiol 53: 239-252

15. Gelb J Jr, Ladman BS, Tamayo M, Gonzalez M, Sivanandan V (2001) Novel infectious bronchitis virus S1 genotypes in Mexico 1998-1999. Avian Dis 45: 1060-1063

16. Gelb J Jr, Wolff JB, Moran CA (1991) Variant serotypes of infectious bronchitis virus isolated from commercial layer and broiler chickens. Avian Dis 35: 82-87

17. Gough RE, Cox WJ, Gutierrez E, MacKenzie G, Wood AM, Dagless MD (1996) Isolation of "variant" strains of infectious bronchitis virus from vaccinated chickens in Great Britain. Vet Rec 139: 552

18. Higgins DG, Sharp PM (1988) CLUSTAL: a package for performing multiple sequence alignment on a microcomputer. Gene 73: 237-244

19. Hofstad MS (1981) Cross-immunity in chickens using seven isolates of avian infectious bronchitis virus. Avian Dis 25: 650-654

20. Huang Y-P, Lee H-C, Cheng M-C, Wang C-H (2004) S1 and N gene analysis of avian infectious bronchitis viruses in Taiwan. Avian Dis 48: 581-589

21. Ignjatovic J, Ashton DF, Reece R, Scott P, Hooper P (2002) Pathogenicity of Australian strains of avian infectious bronchitis virus. J Comp Pathol 126: 115-123 
22. Jackwood MW, Hilt DA, Callison SA, Lee C-W, Plaza H, Wade E (2001) Spike glycoprotein cleavage recognition site analysis of infectious bronchitis virus. Avian Dis 45: 366-372

23. Kant A, Koch G, van Roozelaar DJ, Kusters JG, Poelwijk FA, van der Zeijst BA (1992) Location of antigenic sites defined by neutralizing monoclonal antibodies on the $\mathrm{S} 1$ avian infectious bronchitis virus glycopolypeptide. J Gen Virol 73: 591-596

24. Kwon HM, Jackwood MW (1995) Molecular cloning and sequence comparison of the $\mathrm{S} 1$ glycoprotein of the Gray and JMK strains of avian infectious bronchitis virus. Virus Genes 9: 219-229

25. Kwon HM, Jackwood MW, Gelb J Jr (1993) Differentiation of infectious bronchitis virus serotypes using polymerase chain reaction and restriction fragment length polymorphism analysis. Avian Dis 37: 194-202

26. Lee YJ, Sung HW, Choi JG, Kim JH, Song CS (2004) Molecular epidemiology of Newcastle disease viruses isolated in South Korea using sequencing of the fusion protein cleavage site region and phylogenetic relationships. Avian Pathol 33: 482-491

27. Lee SK, Sung HW, Kwon HM (2004) S1 glycoprotein gene analysis of infectious bronchitis viruses isolated in Korea. Arch Virol 149: 481-494

28. Li H, Yang HC (2001) Sequence analysis of nephropathogenic infectious bronchitis virus strains of the Massachusetts genotype in Beijing. Avian Pathol 30: 535-541

29. Liu S, Chen J, Chen J, Kong X, Shao Y, Han Z, Feng L, Cai X, Gu S, Liu M (2005) Isolation of avian infectious bronchitis coronavirus from domestic peafowl (Pavo cristatus) and teal (Anas). J Gen Virol 86: 719-725

30. Liu HJ, Lee LH, Shih WL, Lin MY, Liao MH (2003) Detection of infectious bronchitis virus by multiplex polymerase chain reaction and sequence analysis. J Virol Methods 109: $31-37$

31. Liu S, Kong X (2004) A new genotype of nephropathogenic infectious bronchitis virus circulating in vaccinated and nonvaccinated flocks in China. Avian Pathol 33: 321-327

32. Mase M, Tsukamoto K, Imai K, Yamaguchi S (2004) Phylogenetic analysis of avian infectious bronchitis virus strains isolates in Japan. Arch Virol 149: 2069-2078

33. Meulemans G, van den Berd TP (1998) Nephropathogenic avian infectious bronchitis viruses. World's Poultry Sci J 54: 145-153

34. Moore KM, Bennett JD, Seal BS, Jackwood MW (1998) Sequence comparison of avian infectious bronchitis virus S1 glycoproteins of the Florida serotype and five variant isolates from Georgia and California. Virus Genes 17: 63-83

35. Nix WA, Troeber DS, Kingham BF, Keeler CL, Gelb J Jr (2000) Emergence of subtype strains of the Arkansas serotype of infectious bronchitis virus in Delmarva broiler chickens. Avian Dis 44: 568-581

36. Raj GD, Jones RC (1996) Local antibody production in the oviduct and gut of hens infected with a variant strain of infectious bronchitis virus. Vet Immunol Immunopathol 53: 147-161

37. Schikora BM, Shih LM, Hietala SK (2003) Genetic diversity of avian infectious bronchitis virus California variants isolated between 1988 and 2001 based on the S1 subunit of the spike glycoprotein. Arch Virol 148: 115-136

38. Sheh HK, Shieh J-H, Chou H-Y, Shimizu Y, Chen J-N, Chang P-C (2004) Complete nucleotide sequences of $\mathrm{S} 1$ and $\mathrm{N}$ genes of infectious bronchitis virus isolated in Japan and Taiwan. J Vet Med Sci 66: 555-558

39. Smati R, Silim A, Guertin C, Henrichon M, Marandi M, Arella M, Merzouki A (2002) Molecular characterization of three new avian infectious bronchitis virus (IBV) strains isolated in Quebec. Virus Genes 25: 85-93 
40. Song C-S, Lee Y-J, Kim J-M, Sung H-W, Lee C-W, Izumiya Y, Miyazawa T, Jang H-K, Mikami T (1998) Epidemiological classification of infectious bronchitis virus isolated in Korea between 1986 and 1997. Avian Pathol 27: 409-416

41. Wang L, Junker D, Collisson EW (1993) Evidence of natural recombination within the S1 gene of infectious bronchitis virus. Virology 192: 710-716

42. Wang L, Junker D, Hock L, Ebiary E, Collisson EW (1994) Evolutionary implications of genetic variations in the $\mathrm{S} 1$ gene of infectious bronchitis virus. Virus Res 34: 327-338

43. Winterfield RW, Hitchner SB (1962) Etiology of an infectious nephritis-nephrosis syndrome of chickens. Am J Vet Res 23: 1273-1279

44. Wu ZQ, Yang QW, Fu C, Zhao XY, Ignjatovic J (1998) Antigenic and immunogenic characterization of infectious bronchitis virus strains isolated in China between 1986 and 1995. Avian Pathol 27: 578-585

45. Yu L, Jiang Y, Low S, Wang Z, Nam SJ, Liu W, Kwang J (2001) Characterization of three infectious bronchitis virus isolates from China associated with proventriculus in vaccinated chickens. Avian Dis 45: 416-424

46. Yu L, Wang Z, Jiang Y, Low S, Kwang J (2001) Molecular epidemiology of infectious bronchitis virus isolates from China and Southeast Asia. Avian Dis 45: 201-209

47. Zwaagstra KA, van der Zeijst BA, Kusters JG (1992) Rapid detection and identification of avian infectious bronchitis virus. J Clin Microbiol 30: 79-84

Author's address: Dr. Xiangang Kong, National Key Laboratory of Veterinary Biotechnology, Harbin Veterinary Research Institute, Chinese Academy of Agricultural Science, 427 Maduan Street, Harbin 150001, P.R. China; e-mail: xgkong@ @vri.ac.cn 